\title{
PSYCHE.
}

\section{SOME OLD CORRESPONDENCE BETWEEN HARRIS, SAY AND PICKERING.-IV.}

\author{
[HARRIS TO SAY.] \\ Milton, Feb'y 21, I825.
}

Dear Sir,

Mr. Nuttall has just sent me your letter of Jany. 8th, with the insects which you committed to his charge. I feel myself under additional obligations to you for your attentions, and am highly gratified with the specimens which I have received from you.

I have met with but one individual of the Dicalus elongatus; and, since my last, have obtained the male of Boletophagus cornutus; Yourspecimen is the female, $\&$ is of a lighter colour, as is represented in the plate attached to Panzer's Prod $[\mathrm{r}]$ omus. Both these insects must be considered as rare in this section of the country. The Nemognatha vittata \& species of Lytta are exceedingly interesting to me. The other insects I have never discovered here; they are therefore valuable additions to my small collection.

Mr. Fuller purchased for me the first vol. of your American Entomology, which is executed in a most beautiful manner, \& must add greatly to the literary fame you already enjoy. You are entirely at liberty to quote my localities for any insects which you may hereafter describe, either in this work or the Journal Acad. Nat. Sc. In your Entomol- ogy I find a species of Smerinthus which I have never noticed: we have one however very much like it, which I have taken to be the ocellata; whether it may be the myops or excaecata I cannot determine, having never seen the descriptions of those species.

Feeling myself the great want of books on American entomology, \& knowing the impossibility of our insects being determined without good descriptions, I have had it in contemplation to describe all the species which I have collected, with the view to publishing a small local Fauna of the insects in this vicinity. With this intention I have resolved to visit Philadelphia the ensuing spring, to request your assistance in determining the genera \& species. You have described so many of our insects which I had considered new, and your descriptions of many of them having never reached me, that I was quite surprised to find that, among those which I have sent you, there were so few nondescripts. I shall immediately obtain the Trans. Am. Philos. Soc. \& if possible the Journal of the Lyceum.

As you may publish your descriptions of Coleoptera before I have an opportunity of consulting with you, I will give the names of such of ours as now occur to me, with some remarks on those whose names you gave me in your last letter. 
Cicindela purpurea is very common in dry pastures. C. hirticollis is rare.* C. sexguttatc, \& 2 varieties, one with an additional spot on the disc, the other without the terminal one, are found in sandy paths. The habitat of punctulata is the same. Elaphrus riparius is rare. Carabus catenulatus is scarce. Agra pensylvanica I have found beneath stones on sunny banks. Omophron limbatum Latr. inhabits near fresh water streams ; Dytiscus marginalis in stagnant water. Several other species of Dytiscus are found, but I have not made out the species. We have a Buprestis which appears to be the virginiensis, but my specimen has not the metallic lustre of yours. Elater oculatus is common; I have not ascertained the habitat of its larva. We have your E.dorsalis, \& E. corticinus. Lycus dimidiatus \& L. reticulatus are generally taken on the wing in the day time, about bushes, \& hedges. Malachius 4-maculatus? the male is distinguished by having the $2 \mathrm{~d}$ joint of the antennæ (not the $3 \mathrm{~d}$ joint, as in Fabricius) dilated, quadrate, $\&$ with a deep indentation. But what is most remarkable is that, even by aid of a powerful magnifier, I could detect only 4 joints to the anterior tarsi. Like others of the genus this species is furnished with with 4 retractile, tridigitated tentacula? or processes, one on each of the thorax \& abdomen. Having fixed my specimen to a card I cannot compare the colours beneath with those of your

\footnotetext{
*In Prof. Peck's cabinet are the only specimens I have seen.
}

vittatus; but those of the superior surface correspond exactly, except the antenna, the first and $2 \mathrm{~d}$ joints of wh'h are rufous, the remainder blackish. Length of the male just $\frac{1}{5}$ inch. The female has the usual number of joints to the anterior tarsi. There some varieties particularly of this sex: In these the thorax is destitute of the black spots; the dilated humeral portion of the margin is extended into a fascia which unites with the suture. This species of Malachius I have found in meadows, on the flowers of Chrysanthemum leucanthemum, in June \& July. We have several species of Ips which are allied to the fasciata. Attagenus pellio is very common in houses, \& a species, or perhaps variety, without the white dot on the elytron. I have met with a Lucanus which corresponds with your parallelus, only that there is no small tooth "on the middle of the inferior inner edge" of the mandibles. Passalus interruptus is common. Diaperis maculata Oliv. is found here upon fungi. Three species of Lytta are also found here, viz: $L$. cinerea on the potato-vine \&c, L. marginata on the Clematis virginiana, \& L. atrata on the Solidago. Bruchus pisi prevails every year. We have your Lamia aspersa, also $L$. nebulosa F. and Callidium bicolor, F.

I will now recur to the insects which I sent you in box I. If No, 2 be Calosoma calidum of Fabricius (which I presume you intended when you wrote calida) that author was mistaken in describing it as apterous; all the specimens which I have seen certainly have 
wings. No. $4 \mathrm{I}$ had taken to be the cisteloides of Schönherr, Aavipes of Paykull. To No. 9 I had fixed the name of 2. cupreus, F.; it is your Pecilia lucubanda; to No. I6, your Amara impunctata, I gave the name of Carabus dispar, Paylkull, or vulgaris, F. I should not have suspected your Harpalus rusticus (No. II) to have belonged to the genus Harpalus, judging from a cursory view, it seems very unlike the other species of that genus. Your $H$. viridis, Nos. 12 and I3, stand in my cabinet by the name of Aneus? F. proteus? Paykull. The latter name appears appropriate from the variety of shades which different individuals exhibit. You will, I hope, excuse my confessing my mistakes, for such I presume they must be; for you have the best means of knowing that these individuals had not been before described, or that I had not rightly made them out. No. $3^{8}$ is not the female of Lampyris corrusca. I have obtained the sexes in coitu, \& the female is not apterous. No. 4I which you mention as a variety of L. laticornis, F. I have found in great numbers on shrubs in July, \& never in company with the laticornis, No. 42: Hence I conclude it must be distinct, \& therefore marked it as the ater? F. No. 47 , your $S$. caudata, stands in my cabinet as the Silpha lapponica, to Fabricius' description of which I thought it corresponded. I cannot discover teeth on the posterior thighs of No. $48, S$. surinamensis F., as described by Fabricius. Is No. 59 the same as Dermestes marmoratus, Knoch, in Melsheimer's catalogue? No. 66 answers the description of Scarabaeus Hecate, Panzer, (Faun. Amer. Boreal. Prod[r]omus). No. 74, your Sc. relictus is very common in certain localities. On May 2 1 st 1822 I saw the ground covered with them at Hoboken, New Jersey ; \& last summer great quantities were exhumed from beneath a dung hill in this vicinity, in all their stages of larva, pupa, \& imago. No. 75 Melolontha quercina, Knoch, is very injurious to fruit trees in June; the larva is equally destructive to the roots of grass. Can No. 82 be a variety of $M$. varians. It has not the ovoid form of the varians, \& seems nearer allied to your iricolor. Trichius scaber diffuses so strong an odour that I have frequently discovered it by that alone, when at the distance of several yards. The larva in habits the trunks of decaying trees.* Melolontha elongata is found in profusion on oaks in June. To No. 9r I gave the name of Trox nigritus, \& to 92 that of $T$. pulverulentus. I omitted in course No. 22 which is my Carabus pusillus, \& No. 33 Elater pumilus. No. 93, to which you assign the name of Tenebrio barbatulus, lives like the molitor about stables, granaries \&c. The larva devours corn; is elongated, depressed, corneous, \& of a yellow colour, with 6 very small legs at the anterior extremity, \& a short tubercle beneath the posterior to assist it in moving. In the pupa the segments of the abdomen are produced, flattened \& finely

*Is Trichius eremicola, Knoch, the Scarabaus ebenus of DeGeer? 
serrated, \& the tail bifurcated. No. 95 is the only species of Meloë I have ever discovered; it is not uncommon in pastures. I cannot reconcile the descriptions of Diaperis viridipennis with my specimens of No. 94. They inhabit beneath the bark of decaying trees. To 99 I gave the name of Curculio hirtus in my collection. No. IO3 I have always taken to be the Megacepha marmorata. No. 106 is the Scolytus cerasi of my cabinet. Is it not of the genus Hylurgus? No. II I you have marked as a variety of Callid. fennicum. Fabricius describes that insect with violaceous elytra. I had marked I I as the flavum, F. In the Stenocorus putator, Peck, the $2 \mathrm{~d}$ and $3 \mathrm{3d}$ joints of the antennæ are each terminated with one rigid spine; \& I agree with you in thinking that it is probably distinct from the bidens \& villosus of Fabricius. 170 is my Donacia attenuata. 127 Crioceris (Lema) trilineata is found on the vines of the potato \& other Solani in June. The eggs are affixed to the leaves, \& immediately on their being hatched the larvæ enter the earth. No. I33 inhabits the leaves of the apple tree. The larva devours the parenchymatous substance of the leaf, the cuticle remaining untouched. Here it changes to a nymph, \& emerges from its retreat only when it has assumed the imago. The larvæ of 130 Imatidium argus, feed upon the leaves of the Convolvuli; those of $\mathrm{I}_{32}$, Cassida aurichal$c e a$, on the leaves of the sweet potato, \& the Solanum dulcamara. Eumolpus auratus I have always found on the Apocynum androscemifolium, and Chrysomela trimaculata on the Asclepias syriaca on which plant the larva \& pupa of the latter are also found. Coccinella 9-notata, \& C. abbreviata inhabit the leaves of the carrot, from which I have obtained the larva \& pupa. Your $C$. bioculata is constantly found in all its stages on the Ligustrum vulgare. I63, your Colaspis ro-notata, I have found only upon the leaves of the oak. No. I 75 is my Helops piceus.

The marine shells which I intended for you, were unfortunately mislaid or lost, \& I have delayed this letter in the hopes of recovering $\&$ sending them by a private conveyance. They were not of much value for rareness or beauty, but were such as are common here, \& which I can therefore replace in the course of the summer.

$$
\begin{aligned}
& \text { With sentiments of respect, } \\
& \text { Yr. obed't friend } \\
& \text { T. Wm. Harris. }
\end{aligned}
$$

[Endorsed with the following notes by Thomas Say] :-

Malachius 4-maculatus Fabr.; it is certainly the $3^{d} j^{\prime} t$. Fab. is right; the ant'r tarsi have 5 very distinct joints. Mal. vittatus some of my spec's have the anten'a dusky at tip. Lucanus parallelus. the fem. has the tooth somet's hardly obvious. Calosoma calida and several others Fab. descr'd as apterous have wings. 

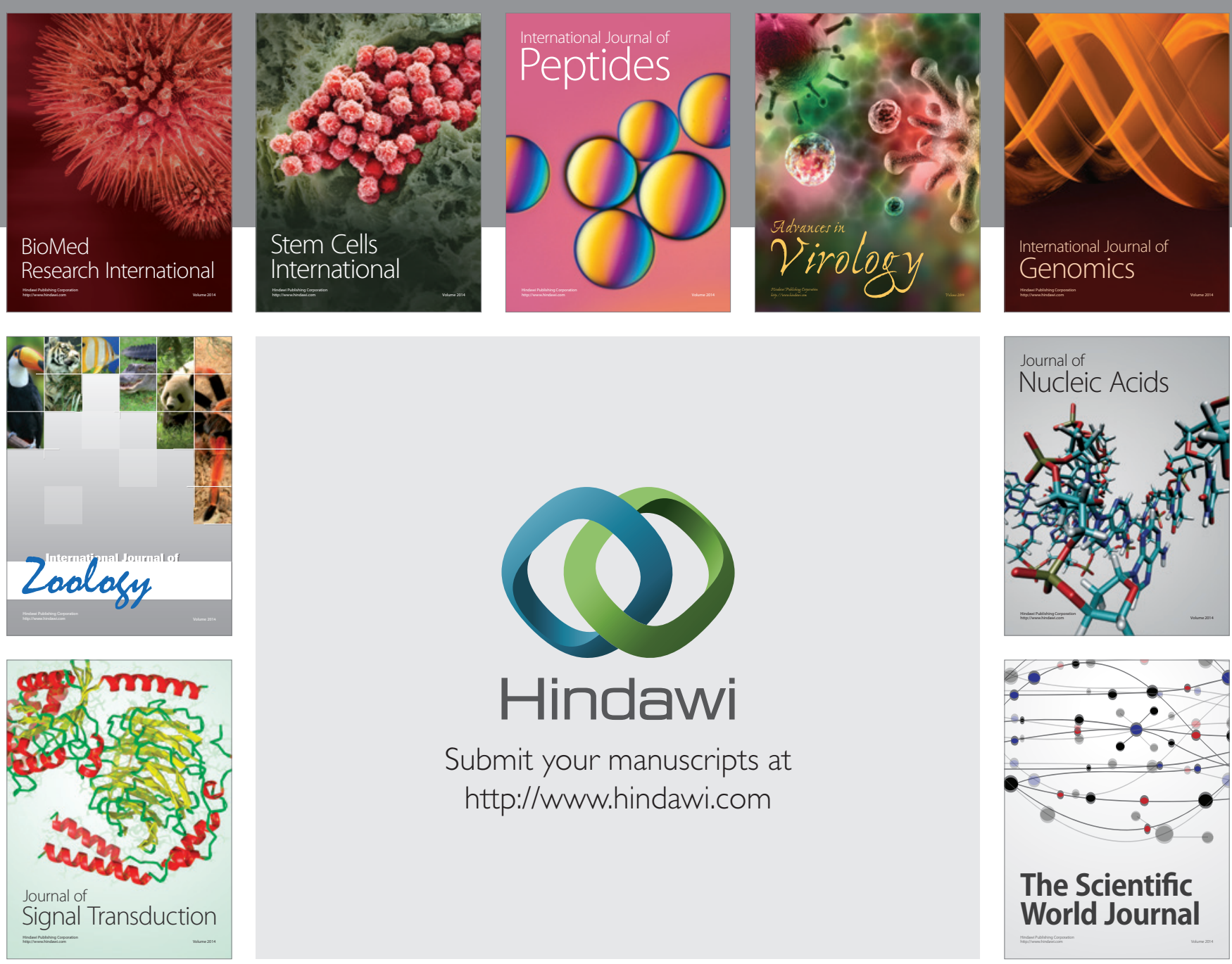

Submit your manuscripts at

http://www.hindawi.com
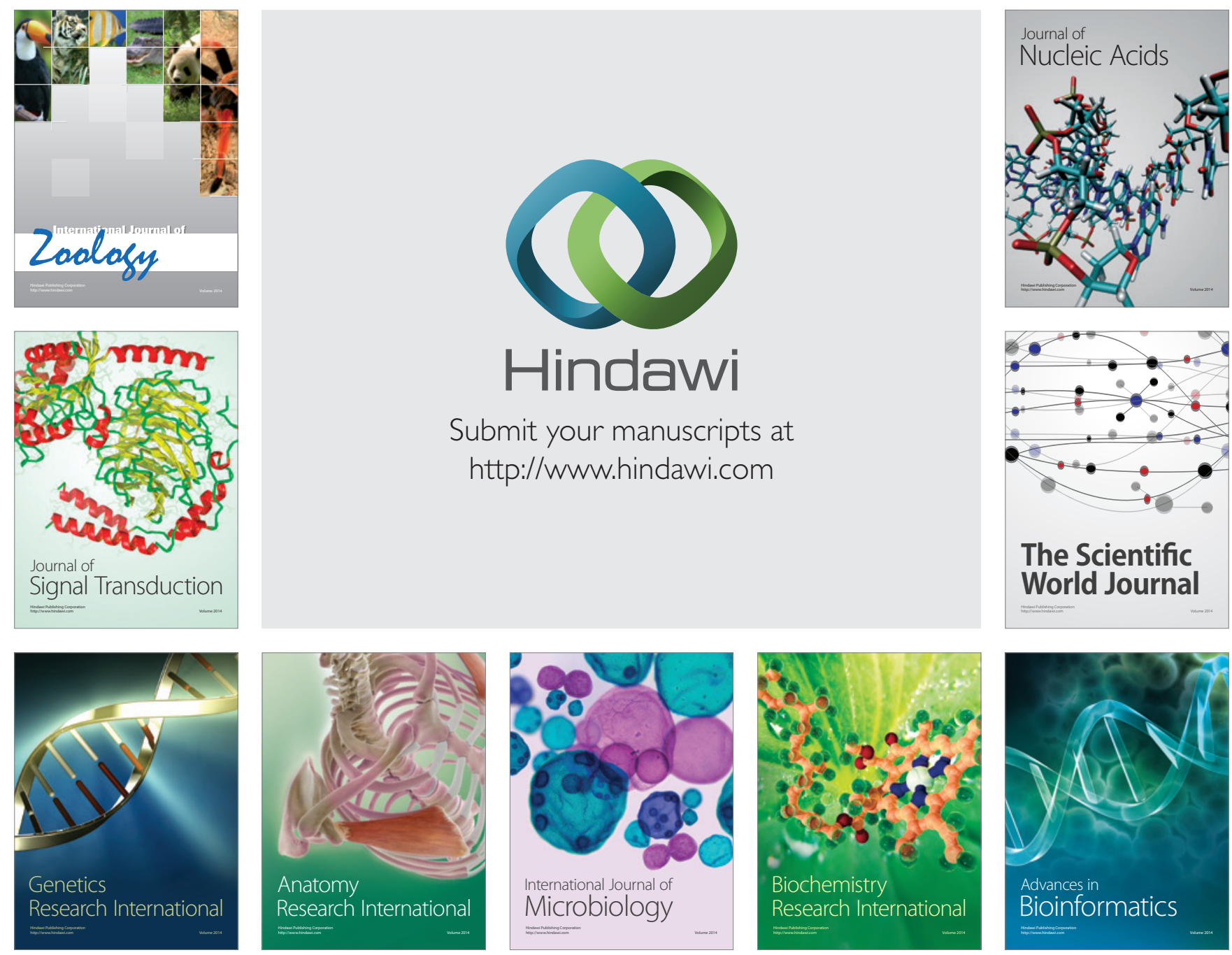

The Scientific World Journal
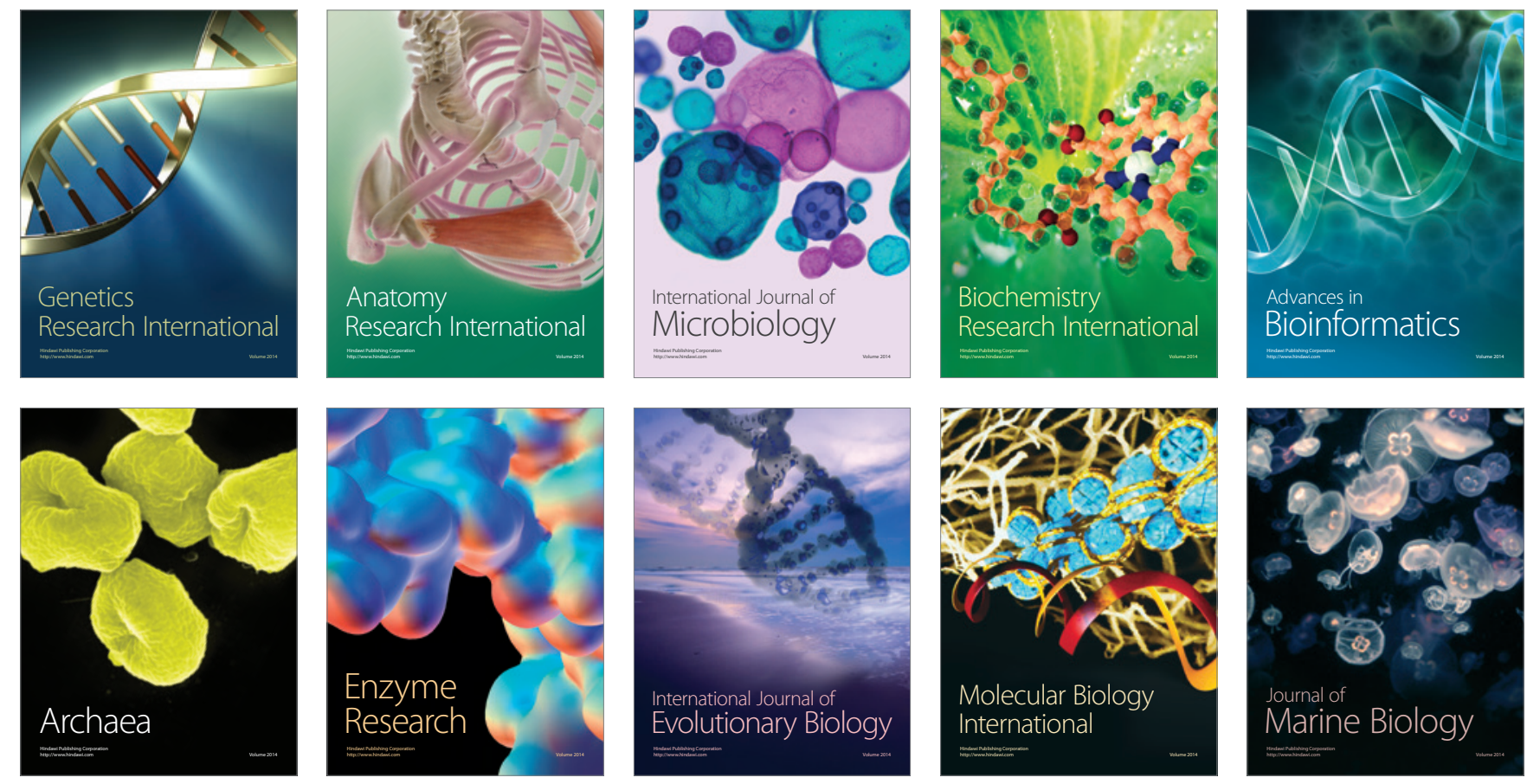